\title{
Synthesis of nitrocarbazole compounds and their electrocatalytic oxidation of alcohol
}

\author{
Yinghong Zhu, Jianqing Zhang, Ziying Chen, Anlun Zhang, Chunan Ma* \\ State Key Laboratory Breeding Base of Green Chemistry Synthesis Technology, College of Chemical Engineering, Zhejiang University of Technology, \\ Hangzhou 310032, Zhejiang, China
}

A R T I C L E I N F 0

Article history:

Received 1 December 2015

Accepted 27 January 2016

Published 5 April 2016

\section{Keywords:}

Nitro-carbazole compounds

Organic electro-catalyst

Indirect electro-oxidation

Selective electro-oxidation

Redox reversibility

\begin{abstract}
A B S T R A C T
Three compounds with nitrocarbazole frameworks were synthesized and their electrochemical reversibility as organic electrocatalysts was studied by cyclic voltammetry. The electrochemical reversibility and oxidation-reduction potential of the compounds were greatly affected by their substituents. The oxidation-reduction potential of the compound with an electron-donating group was negative, while that of the compound with an electron-withdrawing group on the carbazole framework was positive. The electrocatalytic oxidation activities of the nitrocarbazole compounds were investigated through cyclic voltammetry and controlled potential electrolysis at room temperature. The electrocatalysts showed excellent selectivity for $p$-methoxybenzyl alcohol, converting it to the corresponding aldehyde through electro-oxidation with just $2.5 \mathrm{~mol} \%$ of the electrocatalysts presented. The electrocatalysts maintained their excellent electroredox activity following recycling.
\end{abstract}

(C) 2016, Dalian Institute of Chemical Physics, Chinese Academy of Sciences. Published by Elsevier B.V. All rights reserved.

\section{Introduction}

The catalytic oxidation of small organic molecules is an important research area in the field of catalysis. Selective oxidation of alcohols to the corresponding aldehydes and ketones is important in the synthesis of fine chemicals and organic intermediates [1,2]. Many catalysts with high selectivity, stability and low cost have been developed to improve the conversion and selectivity in the oxidation of alcohols to the corresponding aldehydes. For instance, gold-copper bimetallic catalysts [3], and nitrogen-doped carbon nanosphere-supported palladium catalysts [4] have been prepared and used in the catalytic oxidation of benzyl alcohol. Jia et al. [5] reported the selective oxidation of benzyl alcohol to benzaldehyde using alkali-treated ZSM-5 zeolite as a catalyst and $\mathrm{H}_{2} \mathrm{O}_{2}$ as an oxidant. Many re- searchers have also devoted effort to the study of organic catalysts. For example, the organic sulfonate [6], immobilized 2,2,6,6-tetramethylpiperidine- $N$-oxyl (TEMPO) [7] and Lewis acid-activated TEMPO have been studied as catalysts for the oxidation of alcohol. These approaches are limited by the use of either noble metals or high temperature.

Organic electrocatalysis is recognized as an environmentally compatible methodology because it avoids using toxic and dangerous oxidizing or reducing reagents, and most of the reactions can be carried out under mild conditions $[9,10]$. However, in direct electro-oxidation synthesis, the working electrode is easily passivated by the formation of a polymer film on the electrode surface, which can sharply decrease current efficiency. Indirect electro-oxidation with an electron transfer mediator is a good way to avoid passivation of the electrode

\footnotetext{
* Corresponding author. Tel/Fax: +86-571-88320830; E-mail: science@zjut.edu.cn

This work was supported by the Special Program for the National Basic Research Program of China (973 Program, 2012CB722604).

DOI: 10.1016/S1872-2067(15)61047-6 | http://www.sciencedirect.com/science/journal/18722067 | Chin. J. Catal., Vol. 37, No. 4, April 2016
} 
$[11,12]$. Triarylamines have received extensive attention from researchers as a new type of electro-redox mediator because of their broad range of redox potentials. The oxidation potential of triarylamines can become positive after introduction of an electron-withdrawing group [13-18]. Compared with the triarylamine framework, the carbazole framework has better planarity and the substituents have a greater effect on the redox properties [19]. Carbazole compounds have been widely used as fluorescent materials [20], but have not been employed as an electro-redox mediator in electrocatalytic oxidation, especially carbazole compounds with nitro groups. Based on the intrinsic properties of the carbazole framework and strong electron-withdrawing nature of nitro groups, in this paper, nitrocarbazole compounds were synthesized and used as organic electrocatalysts in the mediated electro-oxidation of alcohols at room temperature.

\section{Experimental}

\subsection{Preparation of the organic electrocatalysts [21-25]}

The route used to synthesize carbazole compounds with different substituents is shown in Scheme 1.

3,6-Dibromo-9H-carbazole (1), a solution of $\mathrm{N}$-bromosuccinimide $(0.21 \mathrm{~mol})$ in DMF (80 $\mathrm{mL}$ ) was slowly added to a solution of carbazole $(0.1 \mathrm{~mol})$ in DMF $(20 \mathrm{~mL})$ in an ice bath. After reaction for $30 \mathrm{~min}$, the mixture was poured into ice water $(1 \mathrm{~L})$, and the crude product was collected by filtration to give a blue powder. Recrystallization from $\mathrm{EtOH} / \mathrm{H}_{2} \mathrm{O}$ afforded blue crystals with a yield of $68 \%$. ${ }^{1} \mathrm{H}$ NMR $\left(500 \mathrm{MHz}, \mathrm{CDCl}_{3}\right): \delta$ $8.14(\mathrm{~d}, J=1.9 \mathrm{~Hz}, 2 \mathrm{H}), 8.12(\mathrm{~s}, 1 \mathrm{H}), 7.53(\mathrm{~d}, J=8.6,1.9 \mathrm{~Hz}, 2 \mathrm{H})$, $7.32(\mathrm{~d}, J=8.6 \mathrm{~Hz}, 2 \mathrm{H})$.

3,6-Dimethoxycarbazole (2), in a 100-mL three-necked flask, a solution of sodium methoxide $(0.1 \mathrm{~mol})$ in methanol (15 $\mathrm{mL})$ was stirred at room temperature for $30 \mathrm{~min}$. CuI $(0.02$ mol), 1 (0.005 mol), and DMF (17 mL) were added and then the mixture was heated under reflux for $8 \mathrm{~h}$ under $\mathrm{N}_{2}$ atmosphere. The solution was filtered while hot to remove $\mathrm{CuI}$ and the filtrate was poured into stirred water $(1 \mathrm{~L})$. The resulting precipitate was collected by filtration, washed thoroughly with water, and dried to afford a black powder in a yield of $88 \%$. ${ }^{1} \mathrm{H}$ NMR (500 MHz, $\left.\mathrm{CDCl}_{3}\right): \delta 3.95\left(\mathrm{~s}, 6 \mathrm{H},-\mathrm{OCH}_{3}\right), 7.00(\mathrm{~d}, J=8.4 \mathrm{~Hz}, 2 \mathrm{H})$, $7.28(\mathrm{~d}, J=8.7 \mathrm{~Hz}, 2 \mathrm{H}), 7.53(\mathrm{~s}, 2 \mathrm{H}), 7.79(\mathrm{~s}, 1 \mathrm{H},-\mathrm{NH})$. 3a-3c, a 100-mL two-necked flask equipped with a reflux condenser was charged with a carbazole compound with a $-\mathrm{OCH}_{3}, \mathrm{H}$ or $\mathrm{Br}$ substituent (15.3 mmol), $\mathrm{K}_{2} \mathrm{CO}_{3}$ (76.52 mmol), p-nitrofluorobenzene $(61.4 \mathrm{mmol})$, and DMF $(80 \mathrm{~mL})$. Each reaction mixture was heated under reflux for $12 \mathrm{~h}$, cooled, and then poured into water $(500 \mathrm{~mL})$. Each precipitate was filtered, dried, and recrystallized.

3a, orange powder, yield 66\%. ${ }^{1} \mathrm{H}$ NMR $(500 \mathrm{MHz}$, DMSO-d6): $\delta 8.47$ (d, J = 8.6 Hz, 2H), 7.93 (d, $J=8.6 \mathrm{~Hz}, 2 \mathrm{H}), 7.87$ (d, 2H), 7.52 (d, $J=8.9 \mathrm{~Hz}, 2 \mathrm{H}), 7.08(\mathrm{~d}, J=9.0 \mathrm{~Hz}, 2 \mathrm{H}), 3.90$ (s, $6 \mathrm{H})$.

3b, bright yellow powder, yield 66\%. ${ }^{1} \mathrm{H}$ NMR (500 MHz, $\left.\mathrm{CDCl}_{3}\right): \delta 8.48(\mathrm{~d}, J=9.0 \mathrm{~Hz}, 2 \mathrm{H}), 8.14(\mathrm{~d}, J=7.8 \mathrm{~Hz}, 2 \mathrm{H}), 7.8(\mathrm{~d}, J$ $=9.0 \mathrm{~Hz}, 2 \mathrm{H}), 7.49(\mathrm{~d}, J=8.4 \mathrm{~Hz}, 2 \mathrm{H}), 7.46-7.43(\mathrm{~m}, 2 \mathrm{H})$, 7.35-7.33 (m, 2H).

3c, bright yellow powder, yield 81\%. ${ }^{1} \mathrm{H}$ NMR $(500 \mathrm{MHz}$, $\left.\mathrm{CDCl}_{3}\right): \delta 8.57-8.47(\mathrm{~m}, 2 \mathrm{H}), 8.23(\mathrm{~d}, J=1.9 \mathrm{~Hz}, 2 \mathrm{H}), 7.79-7.71$ $(\mathrm{m}, 2 \mathrm{H}), 7.57(\mathrm{~d}, J=8.7,2.0 \mathrm{~Hz}, 2 \mathrm{H}), 7.35(\mathrm{~d}, J=8.7 \mathrm{~Hz}, 2 \mathrm{H})$.

4-(3,6-Dimethoxy-9H-carbazol-9-yl)aniline (4a), 3a (0.41 mmol) was dissolved in ethanol $(30 \mathrm{~mL})$, and then $\mathrm{SnCl}_{2} \cdot 2 \mathrm{H}_{2} \mathrm{O}$ ( $2.80 \mathrm{mmol}$ ) was added. The reaction mixture was heated under reflux for $15 \mathrm{~h}$ and then cooled to room temperature. Subsequently, the reaction mixture was adjusted to basic $\mathrm{pH}$ with saturated $\mathrm{NaHCO}_{3}$, and then extracted with $\mathrm{CH}_{2} \mathrm{Cl}_{2}$. The organic layer was washed with brine, dried over $\mathrm{Na}_{2} \mathrm{SO}_{4}$, filtered, and concentrated. The residue was purified by silica-gel column chromatography to afford an orange powder in a yield of $75 \%$. ${ }^{1} \mathrm{H} \mathrm{NMR}\left(500 \mathrm{MHz}, \mathrm{CDCl}_{3}\right): \delta 7.57$ (d, $\left.J=2.4 \mathrm{~Hz}, 2 \mathrm{H}\right), 7.33-7.23$ (m, 4H), 7.09-7.01 (m, 2H), 6.90-6.79 (m, 2H), $3.96(\mathrm{~s}, 6 \mathrm{H})$, $3.85(\mathrm{~s}, 2 \mathrm{H})$.

4-(9H-Carbazol-9-yl)aniline (4b), compound 3b (0.09 mol), $10 \% \mathrm{Pd} / \mathrm{C}(0.103 \mathrm{~g})$ and ethanol (20 mL) were added to a 50 -mL round-bottom flask equipped with a stirring bar. The reaction mixture was heated under reflux. Hydrazine monohydrate ( $3 \mathrm{~mL}$ ) was added slowly to the mixture, and then the solution was stirred under reflux for $10 \mathrm{~h}$. The solution was cooled to room temperature, filtered to remove $\mathrm{Pd} / \mathrm{C}$, and then concentrated to afford a light brown viscous liquid in a yield of 80\%. ${ }^{1} \mathrm{H} \mathrm{NMR}\left(500 \mathrm{MHz}^{\mathrm{CDCl}} 3\right.$ ): $\delta 8.15(\mathrm{~d}, J=8.0 \mathrm{~Hz}, 2 \mathrm{H}), 7.41$ $(\mathrm{t}, J=7.5 \mathrm{~Hz}, 2 \mathrm{H}), 7.34-7.26(\mathrm{~m}, 6 \mathrm{H}), 6.88-6.87(\mathrm{~m}, 2 \mathrm{H}), 3.83(\mathrm{~s}$, $2 \mathrm{H})$.

4-(3,6-Dibromo-9H-carbazol-9-yl)aniline (4c), compound $\mathbf{4 c}$ was synthesized according the method used to prepare $\mathbf{4 a}$

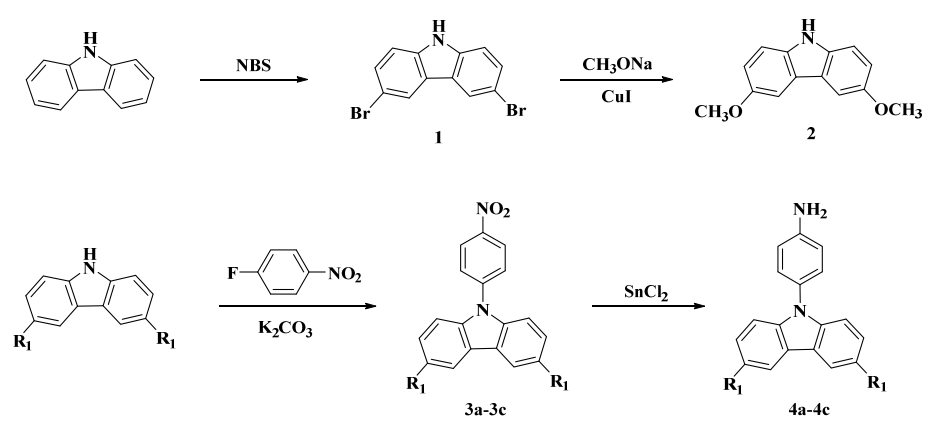

a: $\mathrm{R}_{1}=\mathrm{OCH}_{3} ; \mathrm{b}: \mathrm{R}_{1}=\mathrm{H} ; \mathrm{c}: \mathrm{R}_{1}=\mathrm{Br}$

Scheme 1. Synthesis of the organic electrocatalysts. 
with 3c instead of 3a to afford a white powder in a yield of 92\%. ${ }^{1} \mathrm{H}$ NMR (500 MHz, CD ${ }_{3} \mathrm{CN}$ ): $\delta 8.34(\mathrm{~d}, J=2.0 \mathrm{~Hz}, 2 \mathrm{H}$ ), 7.55 (d, $J=9.0,2.0 \mathrm{~Hz}, 2 \mathrm{H}), 7.25-7.23(\mathrm{~m}, 4 \mathrm{H}), 6.92-6.90(\mathrm{~m}, 2 \mathrm{H})$, $4.74\left(-\mathrm{NH}_{2}, 2 \mathrm{H}\right)$.

\subsection{Electrochemical measurements}

Cyclic voltammetry (CV) was carried on a CHI 660B electrochemical workstation (Shanghai CH Instrument Company, China) equipped with a three-electrode system. All experiments were performed in an undivided electrochemical cell. Glassy carbon (3-mm diameter) served as the working electrode, a platinum sheet $(1 \times 2 \mathrm{~cm})$ as the counter electrode, and $\mathrm{Ag} / \mathrm{AgNO}_{3}$ as the reference electrode. The electrolyte consisted

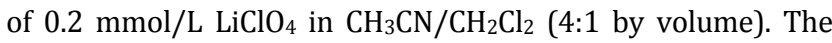
concentration of the organic electrocatalyst was $1 \mathrm{mmol} / \mathrm{L}$. The concentration of $p$-methoxybenzyl alcohol ( $p$-MBzOH) was varied from 3 to $20 \mathrm{mmol}$. The concentration of other substrates was $5 \mathrm{mmol}$. The scan rate was $50 \mathrm{mV} / \mathrm{s}$. All the measurements were performed at room temperature and the CV curves shown are the third stable circle.

Controlled potential electrolysis was performed in an undivided electrochemical cell equipped with a graphite rod (5-mm diameter) as the working electrode, platinum sheet $(1 \times 2 \mathrm{~cm})$ as the counter electrode, and $\mathrm{Ag} / \mathrm{AgNO}_{3}$ as the reference electrode. The electrolyte consisted of $0.2 \mathrm{mmol} / \mathrm{L} \mathrm{LiClO}_{4}$ in $\mathrm{CH}_{3} \mathrm{CN} / \mathrm{CH}_{2} \mathrm{Cl}_{2}$ (4:1 by volume). The concentration of the organic electrocatalyst was $1 \mathrm{mmol} / \mathrm{L}$. The concentration of $p$-MBzOH in the controlled potential electrolysis measurements was varied from 20 to $200 \mathrm{mmol}$. The electrolysis process was performed for $6 \mathrm{~h}$ at room temperature. The major products were detected using GC-MS (Thermo Fisher). The yield of the oxidation products was determined by GC (Agilent 7890A) and calculated by the area normalization method. The organic electrocatalyst was recycled by extracting the organic phase of the reaction liquid, concentration of the organic phase and purification by silica-gel column chromatography.

\section{Results and discussion}

\subsection{Electrochemical properties of the organic electrocatalysts}

The CV curves of the nitrocarbazole-based redox catalysts with different substituents are shown in Fig. 1. The oxidation-reduction potentials of the catalyst with an electron-donating group $\left(-\mathrm{OCH}_{3}\right)$ was negative, while they became positive after introducing an electron-withdrawing group $(-\mathrm{Br})$ onto the carbazole framework. Compound $\mathbf{3 c}$ has a positive oxidation potential of $1.282 \mathrm{~V}$ versus $\mathrm{Ag} / \mathrm{AgNO}_{3}$. Meanwhile, the introduction of a $-\mathrm{OCH}_{3}$ or $-\mathrm{Br}$ substituent led to better oxidation-reduction reversibility than that of the compound with $\mathrm{H}$. The CVs of the substituted carbazole compounds indicate that they are suitable for use as mediators in electrochemical oxidation reactions. However, the electrochemical oxidation-reduction reversibility of the carbazole compounds disappeared when $-\mathrm{NO}_{2}$ was replaced by $-\mathrm{NH}_{2}$ (Fig. 2). A reasonable explanation for this may be that the aminocarbazole com-

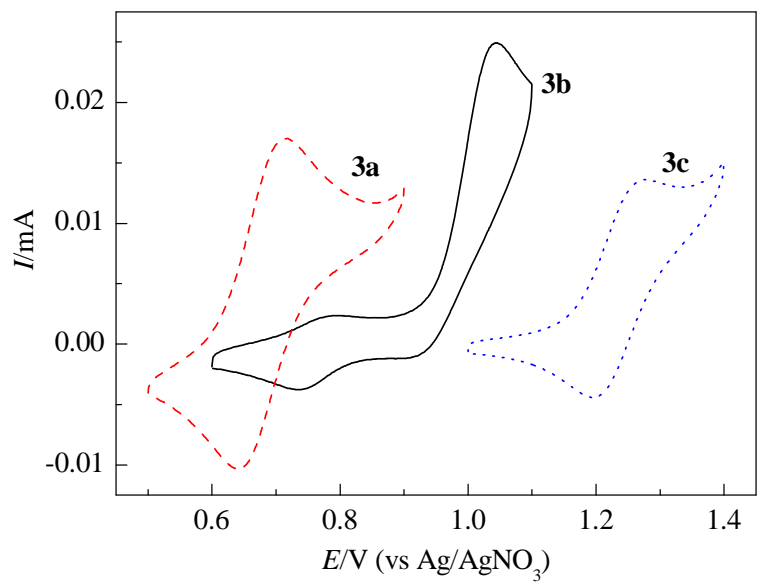

Fig. 1. Cyclic voltammograms of nitrocarbazole-based redox catalysts with different substituents.

pounds tended to form stable ammonium cations after losing an electron, and the reduction increased the delocalization of the conjugated compound. The oxidation potentials $\left(E_{\mathrm{ox}}\right)$, reduction potentials $\left(E_{\mathrm{re}}\right)$ and differences between them $(\Delta E)$ of the carbazole-framework compounds are listed in Table 1.

\subsection{Electrochemical oxidation of an alcohol}

The CVs of $p-\mathrm{MBzOH}$ with and without $\mathbf{3 c}$ are depicted in Fig. 3. The oxidation peak potential for the electro-oxidation of $p$-MBzOH exhibited a 64-mV negative shift from 1.350 to 1.286 $\mathrm{V}$ in the presence of 3c. The energy consumption of the oxidation process was effectively decreased because it could be carried out at a relatively lower potential compared with the electro-oxidation process in absence of 3c. Simultaneously, the oxidation peak current increased markedly. These results show that 3c has excellent catalytic performance in the electro-oxidation of $p$-MBzOH.

Figure 4 presents the $\mathrm{CV}$ curves of different concentrations of $p$ - MBzOH in the presence of $1 \mathrm{mmol} / \mathrm{L}$ of $3 \mathbf{c}$. The oxidation current increased obviously with increasing substrate concentration, indicating that relatively high concentrations of

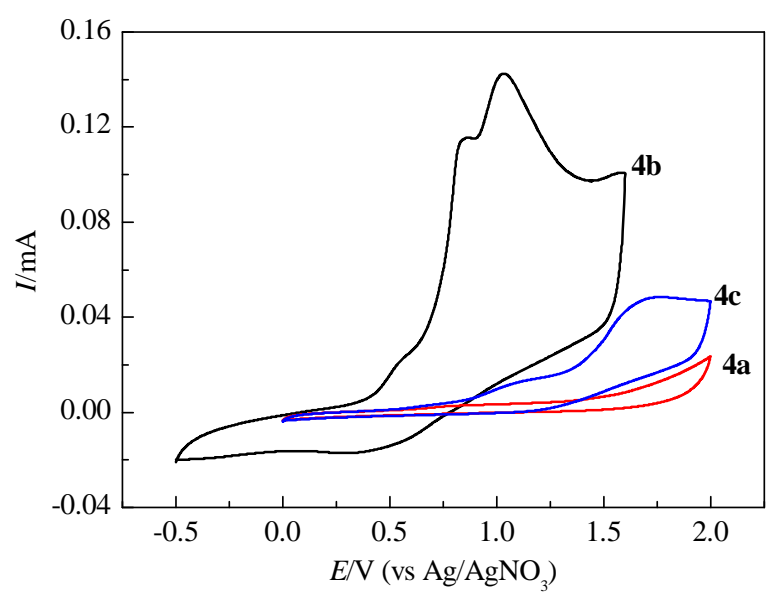

Fig. 2. Cyclic voltammograms of aminocarbazole-based redox catalysts with different substituents. 
Table 1

Oxidation potentials $E_{\mathrm{ox}}$, reduction potentials $E_{\text {re }}$ and difference between the oxidation and reduction potentials $\Delta E$ of the carbazole-based compounds.

\begin{tabular}{|c|c|c|c|c|c|}
\hline \multirow{2}{*}{$\mathrm{R}_{1}$} & \multirow{2}{*}{$\mathrm{R}_{2}$} & \multirow{2}{*}{ Compound } & \multicolumn{2}{|c|}{ Carbazoles } & \multirow{2}{*}{$\Delta E / \mathrm{mV}$} \\
\hline & & & $E_{\mathrm{ox}, 1} / \mathrm{V}$ & $E_{\mathrm{re}, 1} / \mathrm{V}$ & \\
\hline$\overline{\mathrm{OMe}}$ & $\mathrm{NO}_{2}$ & $3 a$ & 0.717 & 0.644 & 73 \\
\hline $\mathrm{H}$ & $\mathrm{NO}_{2}$ & $3 \mathbf{b}$ & 1.051 & 0.905 & 146 \\
\hline $\mathrm{Br}$ & $\mathrm{NO}_{2}$ & $3 c$ & 1.282 & 1.203 & 79 \\
\hline $\mathrm{OMe}$ & $\mathrm{NH}_{2}$ & $4 a$ & - & - & - \\
\hline $\mathrm{H}$ & $\mathrm{NH}_{2}$ & $4 b$ & 1.086 & - & - \\
\hline $\mathrm{Br}$ & $\mathrm{NH}_{2}$ & $4 c$ & 1.709 & - & - \\
\hline
\end{tabular}

p-MBzOH could be electrochemically oxidized and the electrolysis efficiency was improved by $\mathbf{3 c}$. To expand the applicability of $\mathbf{3 c}$ to different substrates, the electrocatalytic performance of the nitrocarbazole compound toward benzyl alcohol with different para-substituents was investigated, as shown in Fig. 5. Even for the substrates with high oxidation potentials, 3c still showed good catalytic oxidation properties.

In an electrolysis system with a volume of $10 \mathrm{~mL}$ and keeping the electrocatalyst concentration at $1 \mathrm{mmol} / \mathrm{L}$, controlled potential electrolysis was conducted using different concentrations of $p-\mathrm{MBzOH}$ at the oxidation potential of the electrocatalyst 3c $(1.28 \mathrm{~V})$ for $6 \mathrm{~h}$. The yields of 4-methoxybenzaldehyde ( $p$-MBA) obtained with different starting concentrations of $p$-MBzOH are illustrated in Fig. 6. When the concentration of $p$-MBzOH was under $40 \mathrm{mmol} / \mathrm{L}$, it was completely transformed to the target product $p$-MBA after $6 \mathrm{~h}$. The yield of $p$-MBA decreased when the concentration of $p-\mathrm{MBzOH}$ was above $80 \mathrm{mmol} / \mathrm{L}$. This is attributed to the low stoichiometric ratio of $3 \mathbf{c}$ to the substrate $(\leq 1: 80)$ at high substrate concentration. The controlled potential electrolysis equation of $p$ - $\mathrm{MBzOH}$ is shown in Eq. 1 and a possible indirect electro-oxidation mechanism for the nitrocarbazole organic cata-

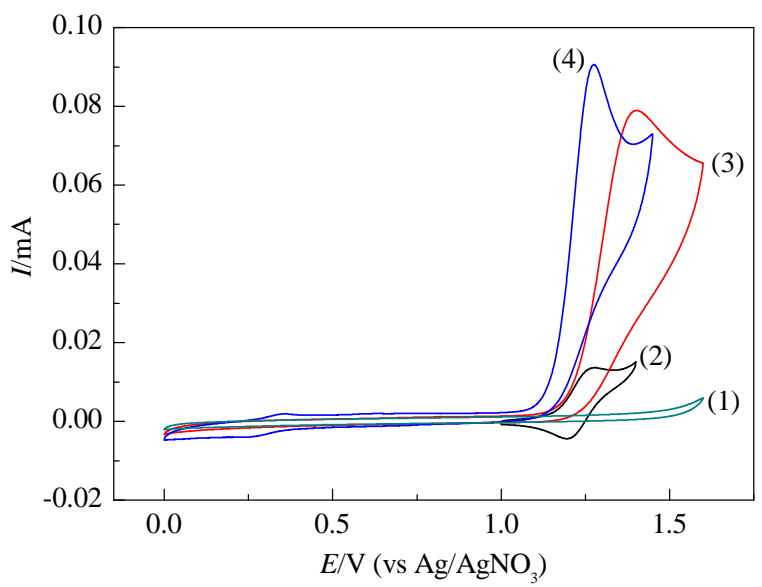

Fig. 3. Cyclic voltammograms of $p$-methoxybenzyl alcohol $(p-\mathrm{MBzOH})$ with and without 3c. (1) blank; (2) $1 \mathrm{mmol} / \mathrm{L}$ of 3c; (3) $5 \mathrm{mmol} / \mathrm{L}$ of $p$-MBzOH; (4) $1 \mathrm{mmol} / \mathrm{L} \mathrm{3c}+5 \mathrm{mmol} / \mathrm{L} p$-MBzOH.

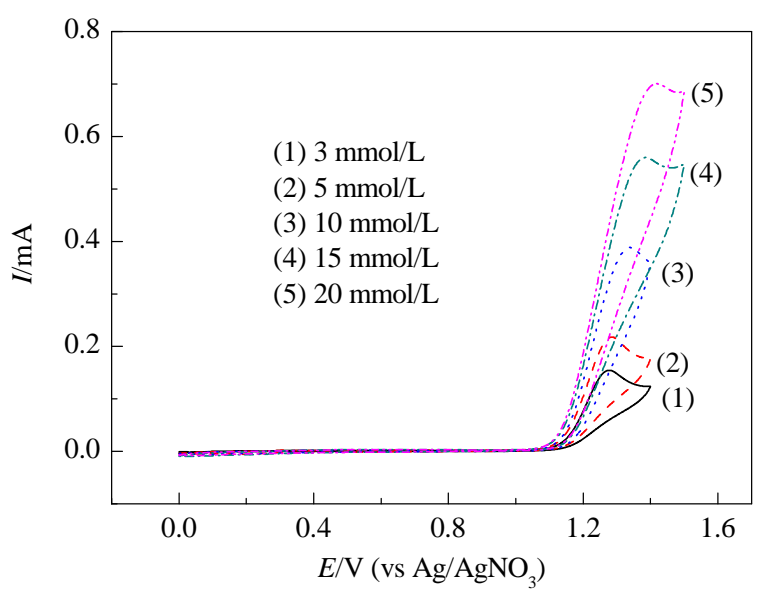

Fig. 4. Cyclic voltammograms of different concentrations of $p$-MBzOH in the presence of electrocatalyst $3 \mathrm{c}(1 \mathrm{mmol} / \mathrm{L})$.



Fig. 5. Cyclic voltammograms of different substrates $(5 \mathrm{mmol} / \mathrm{L})$ in presence of $1 \mathrm{mmol} / \mathrm{L} 3 \mathbf{3 c}$. (1) $p$-MBzOH; (2) $p$-tolylmethanol; (3) phenylmethanol.

lyst is provided in Scheme 2.

\subsection{Recycling of the organic electrocatalyst}

The organic electrocatalyst $\mathbf{3 c}$ was recycled after its first use in controlled potential electrolysis, and the electrochemical properties obtained after recycling are depicted in Fig. 7. $E_{\text {ox }}$ of

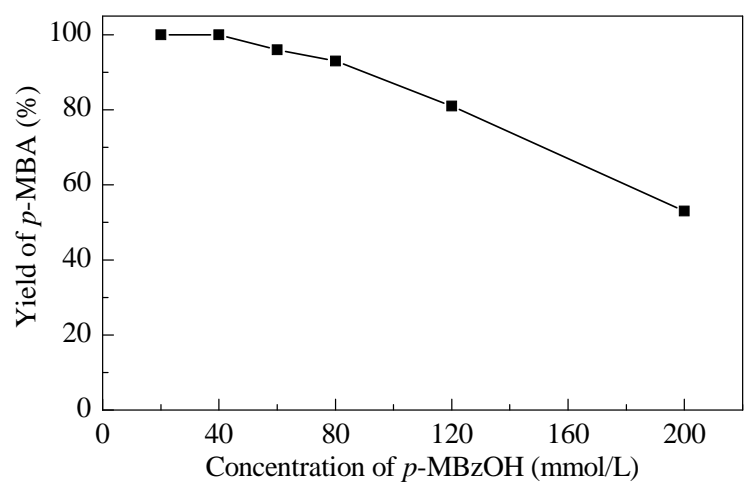

Fig. 6. Yields of $p$-MBA obtained by controlled potential electrolysis of different concentrations of $p-\mathrm{MBzOH}$ using $3 \mathbf{c}$ as a catalyst. 

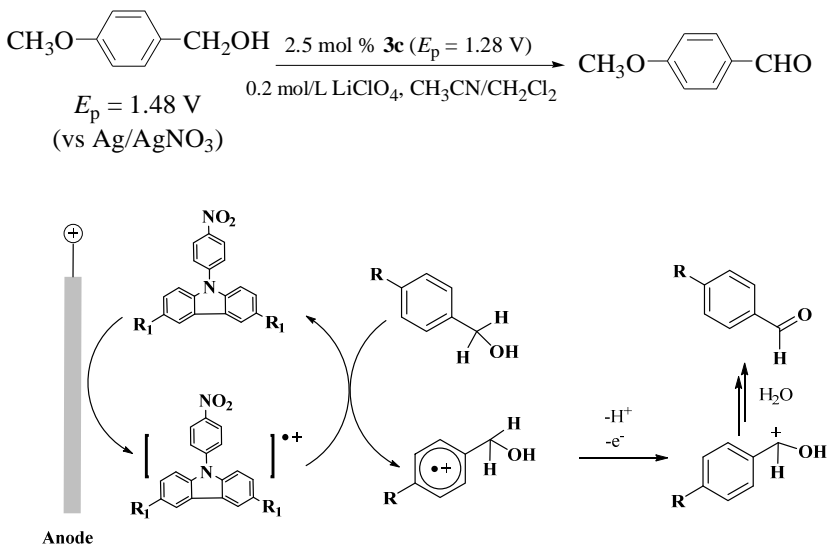

Scheme 2. Proposed indirect electrolysis mechanism of $p-\mathrm{MBzOH}$.

the recovered $3 \mathrm{c}$ was $1.281 \mathrm{~V}, E_{\mathrm{re}}$ was $1.203 \mathrm{~V}$ and $\Delta E$ was about $78 \mathrm{mV}$, indicating that the recycled electrocatalyst $3 \mathrm{c}$ still retains excellent electrochemical reversibility and could be used again as the mediator in the indirect electro-oxidation of alcohols.

\section{Conclusions}

Nitrocarbazole compounds showing good electrochemical reversibility were synthesized by introducing a nitro group onto the carbazole framework. The redox potential of the electrocatalysts could be tuned through modification with different substituents. The oxidation potential of the electrocatalysts became positive after introducing a strongly electron-withdrawing nitro group, which meant that this kind of electrocatalyst was suitable for mediating the electro-oxidative process of different substrates with high oxidation potentials. The nitrocarbazole compounds displayed excellent electrocatalytic oxidative activities in the electro-oxidation of alcohols to the corresponding aldehydes, and the electrocatalysts could be recovered.

\section{Acknowledgments}

The authors gratefully acknowledge Prof. R. Daniel Little of University of California, Santa Barbara, United States.

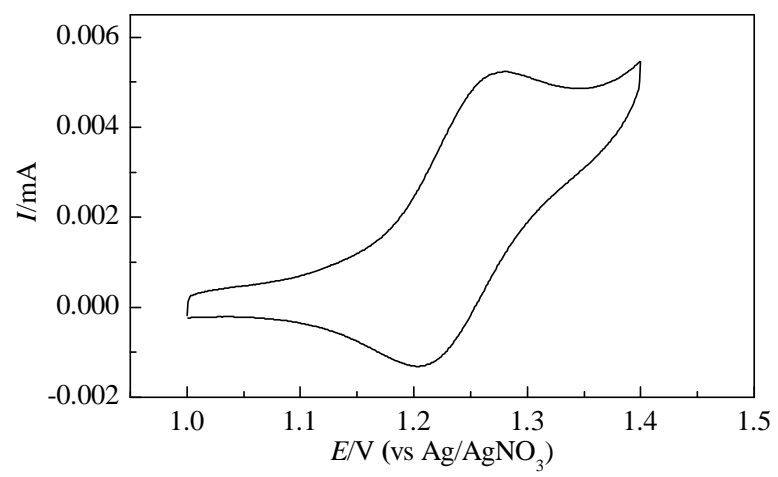

Fig. 7. Cyclic voltammogram of recycled electrocatalyst 3c.

\section{References}

[1] R. A. Sheldon, J. K. Kochi, Metal Catalyzed Oxidations of Organic Compounds: Mechanistic Principles and Synthetic Methodology Including Biochemical Processes, Academic Press, New York, NY, 1981, 326-328.

[2] M. Hudlicky, Oxidations in Organic Chemistry (ACS Monograph, No. 186), American Chemical Society, Washington, DC, 1990, 114-127.

[3] C. D. Pina, E. Falletta, M. Rossi, J. Catal, 2008, 260, 384-386.

[4] Y. Hao, S. Wang, Q. Sun, L. Shi, A. H. Lu, Chin. J. Catal., 2015, 36, 612-619.

[5] A. Z. Jia, L. L. Lou, C. Zhang, Y. Q. Zhang, S. X. Liu, J. Mol. Catal. A, 2009, 306, 123-129.

[6] Y. Y. Yu, B. Lu, X. G. Wang, J. X. Zhao, X. Z. Wang, Q. H. Cai, Chem. Eng. J., 2010, 162, 738-742.

[7] Y. L. Yu, B. J. Gao, Y. F. Li, Chin. J. Catal., 2013, 34, 1776-1786.

[8] T. A. D Nguyen, A. M. Wright, J. S. Page, G. Wu, T. W. Hayton, Inorg. Chem., 2014, 53, 11377-11387.

[9] B. A. Frontana-Uribe, R. D. Little, J. G. Ibanez, A. Palma, R. Vasquez-Medrano, Green Chem., 2010, 12, 2099-2119.

[10] H. J. Schäfer, M. Harenbrock, E. Klocke, M. Plate, A. Weiper-Idelmann, Pure Appl. Chem., 2007, 79, 2047-2057.

[11] E. Steckhan, Angew Chem., 1986, 98, 681-699.

[12] M. Platen, E. Steckhan, Chem. Ber., 1984, 117, 1679-1694.

[13] N. T. Zhang, C. C. Zeng, C. M. Lam, R. K. Gbur, R. D. Little, J. Org. Chem., 2013, 78, 2014-2110.

[14] R. Francke, R. D. Little, J. Am. Chem. Soc., 2014, 136, 427-435.

[15] Y. S. Park, S. C. Wang, D. J. Tantillo, R. D. Little, J. Org. Chem., 2007, 72, 4351-4357.

[16] K. Takahashi, T. Furusawa, T. Sawamura, S. Kuribayashi, S. Inagi, T. Fuchigami, Electrochim. Acta, 2012, 77, 47-53.

[17] S. M. Halas, K. Okyne, A. Fry, Electrochim. Acta, 2003, 48, 1837-1844.

[18] R. Wend, E. Steckhan, Electrochim. Acta, 1997, 42, 2027-2039.

[19] G. S. Liou, S. H. Hsiao, N. K. Huang, Y. L. Yang, Macromolecules, 2006, 39, 5337-5346.

[20] S. C. Dong, Z. Li, J. G. Qin, J. Phys. Chem. B, 2008, 113, 434-441.

[21] H. M. Wang, S. H. Hsiao, J. Polym. Sci. Part A, 2014, 52, 272-286.

[22] M. L. Keshtov, Y. A. Udum, L. Toppare, V. S. Kochurov, A. R. Khokhlov, Mater. Chem. Phys., 2013, 139, 936-943.

[23] K. B. Zheng, W. Y. Lin, L. Tan, Org. Biomol. Chem., 2012, 10, 9683-9688. 


\title{
Graphical Abstract
}

Chin. J. Catal., 2016, 37: 533-538 doi: 10.1016/S1872-2067(15)61047-6

Synthesis of nitrocarbazole compounds and their electrocatalytic oxidation of alcohol

Yinghong Zhu, Jianqing Zhang, Ziying Chen, Anlun Zhang, Chunan Ma*

Zhejiang University of Technology

The redox potential and electrochemical reversibility were greatly improved by introducing nitro-group to the carbazole framework. The nitro-carbazole compound showed high activity on the electro-oxidation of alcohol to corresponding aldehyde.

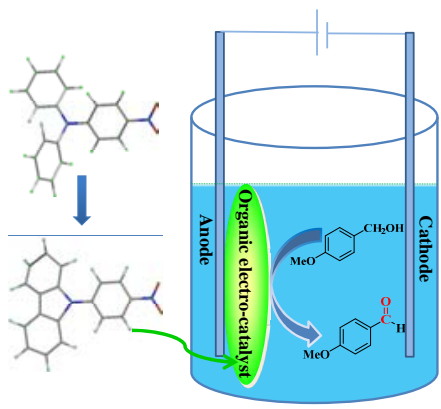

[24] A. N. Bakiev, E. V. Shklyaeva, I. V. Lunegov, I. G. Mokrushin, G. G. Abashev, Russ. J. Gen. Chem., 2014, 84, 1313-1319.

[25] S. F. Wu, Y. Liu, G. P. Yu, J. G. Guan, C. Y. Pan, Y. Du, X. Xiong, Z. G. Wang, Macromolecules, 2014, 47, 2875-2882.

\section{含硝基咔唑类有机电催化剂的合成及其对醇的电催化氧化}

\author{
朱英红, 张健青, 陈姿颖, 张安伦, 马淳安 ${ }^{*}$ \\ 浙江工业大学化工学院, 绿色化学合成技术培育基地, 浙江杭州310032
}

摘要: 有机小分子的电催化氧化是催化领域的一个重要研究内容. 通过醇的选择性氧化合成相应醛或酮类化合物在精细 化学品和有机化学中间体的合成领域均具有十分重要的意义. 有机电催化合成用电子代替强氧化还原剂, 可以使反应在 比较温和的条件下进行. 但在直接电氧化合成反应中, 电极表面容易生成有机聚合物膜, 使电极钝化, 电流效率急剧下降. 而在电子转移媒质作用下的有机电催化反应不仅可以避免电极表面钝化, 还可以控制目标产物的过度氧化. 三芳胺类化 合物是一类新型的电氧化还原媒质, 由于其具有较宽的电化学氧化还原电位已引起研究者的广泛关注. 咔唑类化合物相 比于三芳胺类具有更好的平面性, 使得取代基效应更为显著. 咔唑类化合物被广泛作为荧光材料, 但用于电化学方面的研 究很少. 本文通过在咔唑类化合物中引入具有强吸电子性的硝基以提高该类化合物的氧化电位, 并将其作为有机电催化 媒质, 采用间接电化学氧化的方式, 在室温下研究醇的电化学催化氧化反应, 合成相应醛类化合物.

我们合成了三种含硝基咔唑类有机电催化剂, 通过 ${ }^{1} \mathrm{H}$ NMR对其结构进行了鉴定. 采用循环伏安法测试了该类有机电 催化剂的电化学氧化还原性能. 发现取代基的电子效应对有机电催化剂的氧化还原电位及电化学氧化还原可逆性有很大 的影响, 供电子基 $\left(-\mathrm{OCH}_{3}\right)$ 的引入使氧化电位负移 $(0.717 \mathrm{~V})$, 吸电子基(-Br)的引入使氧化电位明显正移(1.282 V). 同时, 取 代基的引入有效改善了有机电催化剂的电化学可逆性, 从而可以作为有效的电氧化还原媒质应用于电化学氧化反应中. 而当把化合物中的 $\mathrm{NO}_{2}$ 还原为 $\mathrm{NH}_{2}$ 后, 咔唑类化合物的电化学氧化还原可逆性完全消失, 表明硝基的引入对咔唑类有机电 催化剂的电化学性能有很大的影响.

循环伏安结果发现, 在咔唑类硝基化合物的作用下, 对甲氧基苯甲醇 $(p-\mathrm{MBzOH}$ )的电化学氧化峰电位从1.350 V降至 $1.286 \mathrm{~V}$, 表明可以在较低电位下进行电解, 有效降低了电氧化反应的能耗, 同时氧化峰电流明显增加, 说明该类有机电催化 剂对 $p-\mathrm{MBzOH}$ 具有良好的电催化性能. 随着 $p-\mathrm{MBzOH}$ 浓度的增加, 氧化峰电流也明显增大, 说明在咔唑类有机电催化剂 的作用下, $p-\mathrm{MBzOH}$ 可以在比较高的浓度下进行电化学氧化电解. 通过对不同对位取代基的苯甲醇类化合物进行循环伏 安研究, 发现含硝基咔唑类化合物对具有较高氧化电位的反应底物均表现出良好的电催化氧化性能.

在含硝基咔唑类有机电催化剂的氧化电位(1.28 V)和室温下, 对不同浓度的 $p-\mathrm{MBzOH}$ 进行恒电位电解 $6 \mathrm{~h}$, 发现当催化 剂的用量为底物的 $2.5 \mathrm{~mol} \%$ 时, $p-\mathrm{MBzOH}$ 可以完全转化为相应的醛类目标产物. 而且恒电位电解后分离回收的含硝基咔 坐类有机电催化剂仍具有良好的电化学氧化还原可逆性.

关键词: 硝基咔坐类化合物; 有机电催化剂; 间接电氧化; 选择性电氧化; 氧化还原可逆性

收稿日期: 2015-12-01. 接受日期: 2016-01-27. 出版日期: 2016-04-05.

*通讯联系人. 电话/传真: (0571)88320830; 电子信箱: science@zjut.edu.cn

基金来源: 973计划前期研究专项(2012CB722604).

本文的英文电子版由Elsevier出版社在ScienceDirect上出版(http://www.sciencedirect.com/science/journal/18722067). 